\title{
PENERAPANMEDIA FILM STRIP DALAM MENINGKATKAN KETERAMPILAN MEMBACA PEMAHAMAN TEKS CERITA MURID KELAS III SDN 174 SUKADAMAI KECAMATAN SUKAMAJU KABUPATEN LUWU UTARA
}

\begin{abstract}
Indrawati
ABSTRAK

Tujuan penelitian, yaitu mendeskripsikan perencanaan, pelaksanaan, dan evaluasi penerapanmedia film strip dalam meningkatkan keterampilan membaca pemahaman teks cerita murid kelas III SDN 174 Sukadamai Kecamatan Sukamaju Kabupaten Luwu Utara.Pendekatan yang digunakan dalam penelitian ini adalah pendekatan kualitatif. Jenis penelitian ini adalah penelitian tindakan kelas (classroom action research).Penelitian ini dilaksanakan di kelas III Tahun Pelajaran 2011/2012. Instrumen yang digunakan adalah pedoman observasi, tes, dan alat perekam. Teknik analisis data penelitian ini adalah deskriptif kualitatif. Hasil penelitian menunjukkan bahwa (1) Perencanaan penerapan film strip dalam meningkatkan keterampilan membaca pemahaman teks cerita pada murid kelas IIISDN 174 Sukadamai Kecamatan Sukamaju Kabupaten Luwu Utara disusun secara terintegrasi dan kompleksitas sesuai dengan sistematika perencanaan pembelajaran. Namun, pada siklus I, perencanaan belum disusun secara lengkap dengan tidak tercantumnya metode yang dapat menunjang pelaksanaan media film strip. Hal ini telah diperbaiki pada siklus II sehingga keterampilan membaca murid mengalami peningkatan. (2) Pelaksanaan penerapan film strip dalam meningkatkan keterampilan membaca pemahaman teks cerita pada murid kelas IIISDN 174 Sukadamai Kecamatan Sukamaju Kabupaten Luwu Utara siklus I belum terlaksana dengan baik. Guru belum menerapkan media film strip sesuai dengan prosedurnya sehingga proses pembelajaran membaca belum maksimal. Pada siklus II, pelaksanaan film strip sudah sesuai dengan prosedurnya dan dapat diterapkan oleh guru dengan baik tanpa kendala yang signifikan. Hal ini berkontriubusi terhadap peningkatan keaktifan murid dalam membaca. (3) Hasil belajar murid dalam pembelajaran membaca dengan menggunakan film, strip dengan bantuan media Audio-Visual melalui Komputer dan LCD meningkat. Hal ini tampak pada hasil yang diperoleh setiap siklus. Keterampilan membaca siklus 1 mencapai 66,33\%, dan meningkat pada siklus 2 yang mencapai $80,83 \%$.
\end{abstract}

Kata Kunci: media film strip, keterampilan, membaca, cerita

\begin{abstract}
The purpose of the study were described the planning, implementation, and evaluation of penerapanmedia film strips in improving the reading comprehension skills of story text SDN 174 third graders Sukadamai District of Sukamaju Luwu Utara. The approach used in this study was a qualitative approach. This research was action research (classroom action research). Research was conducted in Class III Academic Year 2011/2012 . The instruments used were observation , testing , and recording devices. The technique of data analysis was descriptive qualitative research. The results showed that ( 1 ) Planning application film strips in improving reading comprehension skills in the story text grader IIISDN 174 Sukadamai Sukamaju District of North Luwu arranged in accordance with the complexity of an integrated and systematic learning plan. However, in the first cycle , the planning had not been fully compiled with no inclusion of methods that can support the implementation of the medium of film strips . This had been corrected in the second cycle so that the reading skills of students had increased. ( 2 ) The application of film strips in improving the reading comprehension skills of story text at 174 Sukadamai IIISDN grader Sukamaju District of North Luwu cycle I had not done well . Teachers had not applied a strip of film media in accordance with the procedure so that the process of learning to read was not maximized. In the
\end{abstract}


second cycle , the implementation of the film strips were in accordance with the procedure and can be applied by teachers as well without significant obstacles . This berkontriubusi to increased activity of students in reading . ( 3 ) The results of student learning in learning to read by using a film strip with the help of Audio-Visual media through the computer and the LCD increases. This was evident in the results obtained by each cycle. Skills reading cycle 1 reached $66.33 \%$, and the increase in cycle 2 which reached $80.83 \%$.

Keywords : media film strips , skills , reading, story

\section{Pendahuluan}

Penguasaan keterampilan membaca, seperti halnya ketiga keterampilan berbahasa yang lannya, mengalami suatu proses perkembangan. Membaca menuntut pengalaman, waktu, kesempatan, latihan, keterampilan khusus, dan pengajaran dan bimbingan langsung. Oleh karena itu, pembaca harus dapat menangkap pikiran atau gagasan yang dikemukakan atau disampaikan oleh penulis. Hanya saja tidak semua pembaca dapat menangkap agasan atau pokok pikiran yang disampaikan oleh penulis. Sering kali pembaca kesulitan menentukan pokok pikiran dan pikiran penjelas yang terdapat pada sebuah tulisan sehingga sang pembaca kadang kala keliru atau tidak dapat menangkap gagasan dan pesan yang ingin disampaikan oleh penulis. Hal ini sangat terkait dengan tingkat pengetahuan, pemahaman, dan penguasaan keterampilan yang dibutuhkan dalam membaca.

Finochiaro dan Bonomo (dalam Tarigan, 1985: 11) menyatakan bahwa membaca dapat diartikan sebagai suatu proses untuk memahami yang tersirat yang terdapat dalam hal yang tersurat; melihat pikiran yang terkandung di dalam kata-kata yang tertulis. Secara singkat, dapat dikatakan bahwa readingisbringing meaning to and getting meaning from printedarganizationwritten material 'memetik atau memahami makna yang terkandung di dalam bahasa tertulis'. Seiring dengan hal tersebut para pelajar haruslah dibantu untuk menanggapi atau memberi responsi terhadap lambanglambang visual yang menggambarkan tanda-tanda editor yang sama yang telah mereka tanggapi sebelumnya.

Dalam mengajarkan membaca, anak-anak yang menggunakan metode pengalaman bahasa, bahan bacaan harus berasal dari kanak-kanak itu sendiri agar jalan pikiran dan kata-katanya berasal dari pengalaman bahasa mereka. Jika perlu, yang dibaca itu cerita dari mulut si anak yang ditulis oleh gurunya. Dengan demikian, ketika membaca, anak-anak merasa sungguh-sungguh hidup di alam mereka sendiri dan merasa akrab dengan apa yang dibaca.

Salah satu bahan ajar bahasa Indonesia di SD yang harus mampu dipahami oleh murid sesuai dengan kompetensi dasar (KD) pada semester genap, yaitu membaca pemahaman bahan ajar yang berciri cerita. Cerita merupakan bahan bacaan yang sulit dipahami oleh pembaca. Cerita isinya menceritakan suatu kejadian atau peristiwa. Hal ini sejalan dengan pendapat para ahli bahasa yang menyatakan bahwa cerita adalah karangan yang bersifat subjektif isinya bergantung pada selera pengarang. Maksudnya, sekalipun karangan itu bersumber dari suatu kenyataan, misalnya biografi, tetapi materi cerita dan penyusunannya tidak terlepas dari keinginan pengarang.

Sebenarnya, pembelajaran membaca bahan ajar cerita sudah lama diterapkan di sekolah-sekolah, termasuk di SDN 174 Sukadamai Kecamatan Sukamaju Kabupaten Luwu Utara. Akan tetapi, hasil yang dicapai terkadang belum memuaskan yang dipengaruhi oleh berbagai faktor, 
yaitu sarana, sistem pembelajaran yang diterapkan, dan sebagainya.

Berdasarkan hasil observasi awal dan wawancra dengan guru bahwa hasil pembelajaran membaca bahan ajar cerita bagi murid masih bervariasi, bergantung kondisi pribadi murid. Nilai murid kadang tinggi dan rendah. Hasil belajar membaca murid tahun pelajaran 2011/2012 berkisar pada nilai rata-rata 63. Sementara, tuntutan kurikulum yang berlaku saat ini, yaitu murid diharapkan mampu menguasai keterampilan berbahasa dengan menerapkan standar penilaian rata-rata minimal 65 (Kriteria Ketuntasan Minimal). Rendahnya hasil belajar membaca murid tampak pada ketidakmampuan memahami tema, pesan, latar, tokoh, dan nilai-nilai dalam teks cerita.

Melihat kondisi tersebut di atas, peneliti berusaha memberikan solusi alternatif dalam pengajaran membaca agar permasalahan dan kendala pada murid dan guru dapat teratasi. Solusi yang akan diterapkan dalam pengajaran khususnya membaca adalah menerapkan media pembelajaran yang bervariasi dan kreatif agar murid tidak merasa bosan dalam mengikuti pelajaran. Media yang dimaksud adalah media film strip.

Media filmstrip merupakan pesiar (ekskursi) yang digunakan oleh para peserta didik untuk melengkapi pengalaman belajar tertentu dan merupakan bagian integral dari kurikulum sekolah (Sagala, 2006: 214). Dengan filmstrip sebagai media belajar mengajar anak didik dibawah bimbingan guru mengunjungi mengamati gambar atau slide bentuk visual dengan maksud untuk belajar. Hal ini sangat sesuai untuk meningkatkan pembelajaran membaca cerita karena dengan melihat langsung tayangan gambar dalam bentuk film atau audiovisual, maka murid akan lebih memudahkan memahami teks cerita.
Berdasarkan uraian tersebut, penulis terinspirasi melakukan penelitian dengan harapan dapat memecahkan masalah (problem solving) dalam pembelajaran membaca teks cerita. Penelitian yang diharapkan dapat mengungkap hal tersebut berjudul: Penerapan Film Strip sebagai Media Pembelajaran dalam Meningkatkan Keterampilan Membaca Pemahaman Teks Cerita Murid Kelas III SDN 174 Sukadamai Kecamatan Sukamaju Kabupaten Luwu Utara. Hal ini dilakukan berdasarkan data empiris bahwa penelitian yang relevan masih kurang dilakukan.

Peneliti mengangkat masalah ini dengan pertimbangan: (1) setiap jenjang dan tingkat pendidikah mempunyai hak yang sama untuk diteliti; (2) siswa kelas III harus dibekali yang cukup tentang membaca. Artinya, pembaca mampu memahami makna apa adanya, sesuai dengan makna simbol-simbol bahasa yang ada dalam bacaan; (3) media fil strip yang digunakan agar siswa selalu aktif dan menciptakan suasana pembelajaran yang kooperatif, bersosial, dan meningkatkan kerja sama serta tanggung jawab siswa. Selain itu, untuk menambah wawasan tentang pembelajaran membaca teks cerita dengan menggunakan media film strip perlu dilakukan sebagai upaya meningkatkan pembelajaran bahasa Indonesia serta hasil penelitian ini dapat dijadikan verifikasi dan menambah kepustakaan tentang hasil penelitian tentang keterampilan membaca bahan ajar cerita.

\section{Kajian Teori \\ A. Media Film Strip}

Arsyad (2002: 48) menyatakan bahwa film atau gambar hidup merupakan gambar-gambar dalam frame di mana frame demi frame diproyeksikan melalui lensa proyektor secara mekanis sehingga pada layar terlihat gambar itu hidup. Film bergerak dengan cepat dan bergantian 
sehingga memberikan visual yang kontinu. Sama halnya dengan film, video dapat menggambarkan suatu objek yang bergerak bersama-sama dengan suara alamiah atau suara yang sesuai. Kemampuan film dan video melukiskan gambar hidup dan suara memberinya daya tarik tersendiri. Kedua jenis media ini pada umumnya digunakan untuk tujuan-tujuan hiburan, dokumentasi, dan pendidikan. Mereka dapat menyajikan informasi, memaparkan proses, menjelaskan konsep-konsep yang rumit, mengajarkan keterampilan, menyingkat atau memperpanjang waktu, dan mempengaruhi sikap.

Film memberikan keuntungan sebagai berikut:

1. Film dapat melengkapi pengalamanpengalaman dasar siswa ketika membaca, berdiskusi, berpraktik, dan lain-lain. Film merupakan pengganti alam sekitar dan dapat menunjukkan objek yang secara normal tidak dapat dilihat, seperti cara kerja jantung ketika berdenyut.

2. Film dapat menggambarkan suatu proses secara tepat yang dapat disaksikan secara berulang-ulang jika dipandang perlu. Misalnya, langkahlangkah dan cara yang benar dalam berwudhu. Di samping mendorong dan meningkatkan motivasi, film dan video menanamkan sikap dan segi-segi afektif lainnya. Misalnya, film kesehatan yang menyajikan proses berjangkitnya penyakit diare atau eltor dapat membuat siswa sadar terhadap pentingnya kebersihan makanan dan lingkungan.

3. Film yang mengandung nilai-nilai positif dapat mengundang pemikiran dan pembahasan dalam kelompok siswa. Bahkan, film dan video, seperti slogan yang sering didengar, dapat membawa dunia ke dalam kelas.

4. Film dapat menyajikan peristiwa yang berbahaya bila dilihat secara langsung seperti lahar gunung berapi atau perilaku binatang buas.

5. Film dapat ditunjukkan kepada kelompok besar atau kèlompok kecil, kelompok yang heterogen, maupun perorangan.

6. Dengan kemampuan dan teknik pengambilan gambar frame demi frame, film yang dalam kecepatan normal memakan waktu satu minggu dapat ditampilkan dalam satu atau dua menit. Misalnya, bagaimana kejadian mekarnya kembang mulai dan lahirnya kuncup bunga hingga kuncup itu mekar.

Film strip ialah gambar-gambar yang dirangkaikan dalam satu seri secara berurutan untuk diproyeksikan satu per satu (Subana dan Sunati, 2009: 331). Macammacam film strip antara lain single frame film strip dan double frame film strip.

Pembuatan film strip dapat dilakukan dengan langkah-langkah perencanaan berikut: menguraikan ide, merumuskan tujuan, mempertimbangkan sasaran, membuat rangka outline, mempertimbangkan kebaikan dan keburukan mempergunakan film strip, menulis laporan, membuat story board, menyiapkan skrip, memilih orang-orang yang akan membantu.

Dalam hubungannya dengan pembelajaran, film strip dapat dibuat dalam bentuk slide. Cara ini merupakan cara yang paling mudah. Pertama-tama buatlah visual baik life, grafis, maupun caption dalam skrip dalam bentuk slide. Semua slide harus dibuat dalam format horisontal.

\section{B. Membaca}

Membaca pada hakikatnya adalah suatu yang rumit yang melibatkan banyak hal, tidak sekadar melafalkan tulisan, tetapi juga melibatkan aktivitas visual, berpikir, psikolinguistik, dan metakognitif.Sebagai proses visual, membaca merupakan proses menerjemahkan simbol tulis (huruf) ke 
dalam kata-kata lisan. Sebagai suatu proses berpikir, membaca mencakup aktivitas pengenalan kata, pemahaman literal, interpretasi, membaca kritis, dan pemahaman kreatif.

Klein, dkk. (dalam Rahiem, 2005: 13) mengemukakan bahwa membaca meliputi: "(1) membaca merupakan suatu proses, (2) membaca adalah strategis, dan (3) membaca merupakan interaktif. Membaca merupakan suatu proses informasi dari teks dan pengetahuan yang dimiliki olek pembaca yang mempunyai peranan utama dalam membentuk makna."

Membaca adalah kegiatan interaktif. Keterlibatan pembaca dengan teks bergantung pada konteks. Orang yang senang membaca suatu teks yang bermanfaat, akan menemui beberapa tujuan yang ingin dicapainya, teks yang dibaca seseoang harus mudah dipahami sehingga terjadi interaksi antara pembaca dan teks. Selain itu, Oka (1983: 21) berpendapat bahwa membaca adalah proses pengolahan bacaan secara kritis-kreatif yang dilakukan dengan tujuan memperoleh pemahaman yang bersifat menyeluruh tentang bacaan itu dan penilaian terhadap keadaan, nilai, fungsi, dan dampak bacaan itu.

Tarigan (1987: 8) mengartikan membaca sebagai: "(a) suatu metode yang dipergunakan untuk berkomunikasi dengan diri kita sendiri dan kadang-kadang dengan orang lain, yaitu mengomunikasikan makna yang terkandung dan tersirat pada lambanglambang tertulis; (b) suatu proses memahami yang tersirat dan yang tersurat melihat pikiran yang terkandung dalam kata-kata tertulis. Tingkat hubungan antara makna yang hendak dikemukakan oleh penulis dan penafsiran atau interpretasi pembaca turut menentukan ketepatan membaca."

Hudson (dalam Tarigan, 1987: 7) mengemukakan bahwa membaca adalah suatu proses yang dilakukan serta dipergunakan oleh pembaca untuk memperoleh pesan yang hendak disampaikan oleh penulis melalui media kata-kata/bahasa tulis. Dalam Kamus Besar Bahasa Indonesia (Depdikbud, 2005: 83), membaca adalah melihat serta memahami isi dari sesuatu yang tertulis dengan melisankan atau hanya dalam hati. Selanjutnya, Nurhadi (2005: 123) mengemukakan bahwa membaca adalah aktivitas yang kompleks yang melibatkan berbagai faktor yang datangnya dari dalam diri pembaca dan faktor luar. Selain itu, membaca juga dapat dikatakan sebagai jenis kemampuan manusia sebagai produk belajar dari lingkungan, dan bukan kemampuan yang bersifat instingtif atau naluri yang dibawa sejak lahir. Oleh karena itu, proses membaca yang dilakukan oleh seorang dewasa (dapat membaca) merupakan usaha mengolah dan menghasilkan sesuatu melalui penggunaan modal tertentu.

\section{Membaca Pemahaman sebagai Salah Satu Pembelajaran Membaca di SD}

Membaca bergantung pada pengalaman. Jika sesuatu kata tidak mempunyai hubungan dengan pengalaman, maka hal itu perlu diterjemahkan ke dalam kata yang sudah diketahui. Selain itu, kemampuan mental atau inteligensi mempunyai pengaruh terhadap proses pemahaman dalam membaca pada setiap jenjang pendidikan.

\section{Keterampilan}

pemahaman merupakan keterampilan mengembangkan kemampuan bahasa. Kemampuan membaca juga lebih banyak dikembangkan melalui bahasa tertulis, tetapi tidak bisa disangkal juga pengembangan keterampilan bahasa dalam pemakaian bahasa lisan.

Mengenai penelitian pemahaman, ada beberapa pendapat yang satu dengan yang lainnya saling melengkapi (Wiryodijoyo, 1989: 15), yaitu: 
1. untuk menilai pemahaman harfiah dalam membaca, digunakan pertanyaan mengenai teks. Dipakai juga teks penyimpulan isi bacaan, karena yang terakhir ini merupakan pusat dari proses pemahaman;

2. tes isian dan pilihan ganda dapat mengukur keterampilanketerampilan yang sama. Untuk mengukur pemahaman, pelaksaaaan teks pemahaman berbeda-beda sesuai dengan tuntutan pelajaran yang dites.

Selanjutnya, Suhendra (1992: 3) mengemukakan bahwa membaca memahami merupakan kegiatan membaca yang sesungguhnya yang ditunjukan kepada kemampuan memahami bacaan secara tepat dan cepat. Dalam proses membaca ini, terlihat aspek-aspek berpikir seperti mengingat, memahami membandingkan, menemukan, mengorganisasikan, dan pada akhirnya merupakan sesuatu yang terkandung dalam bacaan.

\section{Pembelajaran Membaca di SD}

Pembeajaran membaca di tingkat SD menekankan pada tujuan pemahaman, penyerapan informasi perolehan kesan dan pesan, atau gagasan yang tersurat maupu yang tersirat. Untuk tujuan tersebut seorang murid harus dapat mengenal kata demi kata, pemahaman kelompok kata/frasa, klausa, kalimat atau teks secara keseluruhan. Selain itu, juga dilakukan denqan berbagai tingkat kecepatan, bergantung kenada tujuan membaca serta kondisi bahan bacaan.

Berdasarkan uraian di atas jelas bahwa kegiatan membaca yang dilaksanakan di SD melibatkan pemikiran, penalaran, emosi, dan sikap murid sesuai dengan tema dan jenis bacaan yang dihadapinya. Untuk mengembangkan kemampuan murid memahami bacaan,
Supratiningsih (2005: 15) mengemukakan pembelajaran membaca sebagai berikut:

\section{Pemahaman Harfiah}

Pemahaman harfiah membimbing murid untuk menemukan infromasi yang secara jelas diungkapkan dalam bacaan. Rancangan pertanyaan ditujukan untuk melatih murid mengenal dan mengingat kemballi suatu fakta atu kejadian.

\section{Mengorgaisasi}

Dalam

menghendaki murid menganalisis, mensintesis, dan mengorganisasi buah pikiran atau intormasi yang dikemukakan secara eksplisit dalam karangan. Tugastugas mengorganisasi menurut Supratiningsih (2005: 15) adalah:mengklasifikasi;meragakan dengan menggunakan pernyataan-pernyataan langsung atau pernyataan yang diparafrasekan; dan mengikhtisarkan atau membuat rangkuman mensitesiskan.

\section{Pemahaman Inferensial}

Pemahaman inferensial ditunjukkan kepada murid bila dapat mencari kesimpulan dan hal-hal yang diketahui dari bacaan. Pertanyaan-pertanyaan menurut Supratiningsih (2005: 16) hendaknya merangsang jawaban murid di luar halaman bacaan.

\section{Pemahaman Evaluasi}

Bia murid dapat menunjukkan tilikan evaluatif dengan membandingkan buah pikiran yang disajikan karangan dengan kriteria yang ada dalam dirinya atau kriteria dari sumber lain, maka murid tersebut telah mempunyai kemampuan pemahaman evaluasi.

\section{Pemahaman Apresiasi}

Pemahaman apresiasi berhubungan dengan psikologis dan estetis murid. Selain itu, membimbing murid mengenai teknik- 
teknik, bentuk, gaya, serta struktur kata. Pertanyaan pada kategori ini dapat diarahkan kepada cara pengarang merangsang emosi pembaca.

\section{E. Cerita sebagai Bahan Ajar Pembelajaran Membaca Pemahaman}

Cerita adalah serangkaian peristiwa yang berusaha menjawab pertanyaan tentang apa yang terjadi atau bagaimana proses terjadinya sesuatu peristiwa. Untuk memahami konsep istilah cerita dipaparkan beberapa pengertian cerita. Cerita sebagai pengisahan yang berhubungan dengan penyajian berupa peristiwa. Pokok masalahnya dengan suatu peristiwa yang disusun dalam bentuk cerita.

Keraf (2005:

mengidentifikasikan cerita sebagai suatu bentuk paparan yang berusaha menggambarkan dengan sejelas-jelasnya kepada pembaca maupun pendengar suatu peristiwa yang telah terjadi. Cerita sebagai perbuatan atau tindakan yang terjadi dalam suatu rangkaian waktu. Apa yang terjadi tidak lain dari tindak tanduk yang dilakukan oleh tokoh-tokoh dalam suatu rangkaian waktu. Cerita adalah suatu peristiwa atau kejadian.

Keraf (2005: 140) menyatakan bahwa bercerita adalah menyampaikan serangkaian kejadian menurut urutan terjadinya, dengan maksud memberi arti kepada sebuah kejadian atau serentetan kejadian, dan agar pembaca dapat memetik hikmahnya dari cerita itu. Dengan kata lain, cerita ini hendak memenuhi keinginan pembaca yang selalu bertanya-tanya. "Apa yang terjadi?' Penataan peristiwa didasarkan alas urutan waktu ( kronologis).

Ambo Enre (1994: 90) mengatakan bahwa cerita adalah karangan yang bersifat subjektif. Isinya bergantung pada selera pengarang. Maksudnya, sekalipun cerita itu bersumber dari suatu kenyataan, misalnya biografi, namun materi cerita dan penyusunannya tidak terlepas dari keinginan pengarang. Cerita dapat berisi fakta yang benar-benar terjadi, dapat pula berisi sesuatu yang khayali. Cerita yang berupa fakta misalnya otobiografi atau biografi seseorang tokoh terkenal. Isi wacana itu benar-benar nyata atau berdasarkan fakta sejarah yang tidak dibuatbuat. Namun, cerpen, novel, roman, hikayat, drama, dongeng, dan lain-lain digolongkan cerita yang khayali karena disusun atas dasar imajinasi seseorang pengarang yang tidak pernah terjadi.

Dalam cerita sering terlihat dialog tokoh-tokoh cerita, di samping uraian biasa. Dialog cerita memang terasa lebih hidup dan menarik sehingga lebih dapat mengasyikkan bagi pembaca. Lukisan watak, pribadi, kecerdasan sikap, dan tingkat pendidikan tokoh dalam cerita yang disuguhkan sering dapat lebih tepat dan mengena apabila ditampilkan lewat dialogdialog. Tokoh yang kejam, buta huruf atau lemah lembut yang sangat penyantun akan lebih hidup apabila diceritakan dalam bentuk percakapan, daripada diceritakan dengan uraian biasa.

Cerita rekaan adalah cerita prosa.Dalam pengertian kesusasteraan sering disebut fiksi (berasal dari bahasa Inggris fiction) atau prosa rekaan atau cerita rekaan, yaitu suatu cerita yang dihasilkan oleh daya khayal atau imajinasi pengarang (Rahmanto, 1998: 15).Cerita rekaan mengisahkan berbagai masalah hidup dan kehidupan manusia dalam hubungan dengan sesama manusia dan lingkungannya.Dengan demikian, cerita rekaan sebenarnya merupakan hasil dialog, renungan, dan reaksi pengarangnya terhadap kehidupan lingkungannya.Nurgiyantoro (2008: 2) menjelaskan bahwa prosa dalam pengertian fiksi, yaitu teks naratif atau wacana naratif yang berarti cerita rekaan atau cerita khayalan. 
Mustopo (1983: 35) mendefisinikan cerita rekaan sebagai suatu bentuk cerita atau prosa kisahan yang mempunyai pemeran, pelaku, peristiwa, dan alur yang dihasilkan oleh daya khayal atau imajinasi.Suharianto (1982: 27) menjelaskan bahwa cerita rekaan atau prosa, ciri khasnya adalah bentuknya yang bersifat pembeberan perasaan yang dipikirkan pengarangnya secara terperinci, adanya pembagian kesatuan-kesatuan makna dalam wujud paragraf atau alinea dan kekhasan penggunaan bahasa yang konstruktif. Aminuddin (1990: 66) menyatakan bahwa cerita rekaan adalah kisahan atau cerita yang diemban oleh pelaku-pelaku tertentu dengan pemeran, latar tahapan, dan rangkain cerita tertentu yang bertolak dari hasil imajinasi pengarangnya sehingga menjalin suatu cerita. Suatu karya yang menceritakan sesuatu yang bersifat rekaan khayalan sesuatu yang tidak terjadi sungguh-sungguh sehingga dia tidak perlu dicari kebenarannya dalam dunia nyata.

\section{Metode Penelitian}

Penelitian ini digolongkan ke dalam penelitian tindakan kelas. Penelitian tindakan kelas ini dilakukan untuk meningkatkan keterampilan membaca pemahaman teks cerita pada murid kelas III SDN 174 Sukadamai Kecamatan Sukamaju Kabupaten Luwu Utara. Mekanisme pelaksanaannya dengan dua siklus. Setiap siklus masing-masing dilaksanakan dengan tiga tahap, yaitu tahap (1) perencanaan, (2) tindakan dan pelaksanaan, (3) refleksi. Siklus penelitian ini dilakukan berdasarkan daur ulang penelitian tindakan menurut Arikunto, dkk. (2008: 16). Instrumen dan teknik yang digunakan dalam penelitian ini adalah pedoman observasi, wawancara, pencatatan, dan tes.Teknik analisis data hasil penelitian dilakukan dengan menggunakan analisis deskriptif untuk mengukur kemampuan membaca hasil tes penelitian (1 kali pembagian tes) setiap siklus dengan menggunakan distribusi frekuensi dan persentase.Analisis kualitatif dilaksanakan sesuai dengan kecenderungan yang terjadi pada setiap siklus dengan melakukan penilaian secara verbal (aktivitas yang diamati).Indikator keberhasilan penelitian adalah apabila hasil tes menunjukkan peningkatan kemampuan membaca pemahaman cerita siswa yang tuntas belajar. Siswa dikatakan tuntas belajar (Usman, 1997: 65) apabila memperoleh skor minimal $65 \%$ dari skor ideal dan tuntas klasikal $85 \%$ dari jumlah siswa telah tuntas belajar.

\section{Hasil Penelitian}

Pada bab ini dibahas tentang data yang telah dipaparkan dalam penyajian hasil analisis data. Fokus pembahasan adalah aktivitas guru dan murid dalam pembelajaran membaca dengan menggunakan media Audio-Visual melalui Komoputer dan LCD di Kelas III. Pembahasan didasarkan teori yang berkaitan dengan pengimplementasian film strip dengan bantuan media Audio-Visual melalui Komputer dan LCD untuk mengefektifkan pembelajaran membaca yang terdiri atas (1) perencanaan pembelajaran, (2) pelaksanaan pembelajaran, dan (3) hasil pembelajaran.

Pembahasan hasil penelitian terdiri atas (1) perencanaan, (2) pelaksanaan, dan (3) evaluasi hasil peningkatan minat belajar murid dalam belajar. Ketiga bagian ini dibahas sebagai berikut:

A. Perencanaan Penerapan Film Strip dalam Meningkatkan Keterampilan Membaca Pemahaman Teks Cerita pada Murid Kelas III SDN 174 Sukadamai Kecamatan Sukamaju Kabupaten Luwu Utara 
Berdasarkan data hasil penelitian tindakan siklus 1 dan tindakan siklus 2,terungkap bahwa perencanaan yang sudah dirancang guru telah terdapat unsurunsur(1) tema/topik pembelajaran, (2) tujuan pembelajaran yang hendak dicapai, (3) alatbantu mengajar yaitu berupay?/m strip dengan bantuan media Audio-Visual melaluiKomputer dan LCD yang sesuai dalam mencapai tujuam pembelajaran yang diharapkan, (4) tehnik dan pengalaman belajar murid serta guru, yang berupa kegiatan belajar mengajar (KBM), (5) materi pembelajaran, dan (6) tersedianya lembar format proses pembelajaran dengan menggunakan film strip dengan bantuan media Audio-Visual melalui Komputer dan LCD dan alat evaluasi belajar. Komponen tersebut terdapat dalam semua perencanaan yang telah dirancang peneliti dan guru secara kolaboratif, baik pada siklus 1 maupun siklus 2.

Hasil penelitian pembelajaran membaca dengan menggunakan film strip dengan bantuan media Audio-Visual melalui Komputer dan LCD terungkap bahwa guru telah membuat model rancangan pembelajaran membaca dengan menggunakan film strip dengan bantuan media Audio-Visual melalui Komputer dan LCD dalam bentuk rencana pelaksanaan pembelajaran (RPP) sebelum melaksanakan pembelajaran di kelas.

Sebagaimana fokus dalam penelitian yang dilakukan adalah minat belajar murid dalam pembelajaran membaca. Olehnya itu guru bersama peneliti secara kolaboratif merancang suatu pembelajaran yang dapat meningkatkan minat belajar murid tersebut dalam pembelajaran membaca, sehingga nantinya murid dapat memahami bacaan dengan baik.

Dalam mencapai tujuan pembelajaran, guru menggunakan pendekatan proses belajar membaca yang terdiri atas 3 tahap yaitu (1) Tahap Persiapan membaca, (2) Tahap Pelaksanaan membaca, dan (3) tahap akhir/tindak lanjut . Pelaksanaan ketiga tahapan ini sesuai dengan tahapan pendekatan proses dalam pembelajaran membaca (process approach) yang diimplemantasikan dengan memanfaatkan film strip dengan bantuan media Audio-Visual melalui Komputer dan LCD sebagai media pengajaran dalam pembelajaran membaca.

Berdasarkan rancangan pembelajaran yang dibuat guru dan peneliti secara kolaboratif melalui proses modifikasi dan disesuaikan dengan teori-teori pembelajaran yang relevan, maka setiap tahap pembelajaran terbukti efektif. Keefektifan tersebut dapat dilihat dari kesesuaian rencana pembelajaran dengan kebutuhan pembelajaran, baik dari aspek guru dan murid, tujuan pembelajaran maupun kondisi pembelajaran yang direncanakan.

\section{B. Pelaksanaan Penerapan Film Strip dalam Meningkatkan Keterampilan Membaca Pemahaman Teks Cerita pada Murid Kelas III SDN 174 Sukadamai Kecamatan Sukamaju Kabu paten Luwu Utara}

\section{Tahap Persiapan Pembelajaran Membaca}

Dari hasil penelitian tindakan siklus 1 dan tindkan siklus 2, terungkap aktivitas guru dan murid sebelum pelaksanaan pembelajaran membaca dengan menggunakan film strip dengan bantuan media Audio-Visual melalui Komputer dan LCD, terlebih dahulu guru melakukan persiapan. Hal ini dilakukan dengan pertimbangan sebelum masuk dalam pelaksanaan membaca, murid sudah benarbenar siap untuk mengikuti pembelajaran membaca, serta menyediakan dan mangatur media yang akan digunakan yaitu film strip 
dengan bantuan media Audio-Visual melalui Komputer dan LCD. Dalam tahap persiapan atau tahap pra baca ini guru bertindak sebagai mediator dan fasilitator guna tercapainya tujuan pembelajaran yang diharapkan.

Pada tahap persiapan, guru mengelola kelas dengan baik, yaitu membimbing dan memotivasi murid agar siap mengikuti pembelajaran membaca yang akan diajarkan, sehingga murid termotivasi untuk tertarik mengikuti pelajaran. Terkait dengan upaya pencapaian tujuan pembelajaran yang telah ditetapkan, pembelajaran membaca perlu diingatkan kembali kepada murid. Kegiatan mengingat kembali mated prasyarat dapat dilakukan dengan cara mengaitkan antara pembelajaran membaca yang lalu dengan pelajaran membaca yang akan diajarkan sekarang, keterkaitan yang terbentuk akan menumbuhkan suatu pemahaman bagi diri murid. Kegiatan mengingatkan kembali pelajaran yang lalu kepada murid pada siklus 1 guru tidak melakukan kegiatan tersebut, nanti pada saat tindakan siklus 2 barulah guru melakukan kegiatan tersebut. Meskipun demikian tahap persiapan yang telah dilakukan guru pada saat pembelajaran berlangsung dengan efektif selama pembelajaran baik itu pada tindakan siklus 1 dan tindakan siklus 2 . Hal ini dapat kita lihat pada antusias murid selama mengikuti pembelajaran, dimana murid dengan semangat mengikuti pelajaran membaca yang diajarkan guru.

\section{Tahap Pelaksanaan}

Dari data hasil penelitian tindakan siklus 1 dan tindakan siklus 2, terungkap pada tahap pelaksanaan pembelajaran membaca dengan menggunakan film strip dengan bantuan media Audio-Visual melalui Komputer dan LCD, guru menampilkan bacaan yang telah disediakan dan diatur dengan menggunakan film strip dengan bantuan media Audio-Visual melalui Komputer dan LCD, kemudian murid mengamati dan mendengarkan bacaan yang ditampilkan tersebut dengan seksama. Hal ini dilakukan untuk mempermudah murid mengamati dan mendengarkan bacaan yang diajarkan guru secara langsung, karena dengan mengalami, melihat dan mendengarkan secara langsung bacaan dapat menarik perhatian murid, sehingga motivasi belajar murid terbangun, serta Murid sangat antusias mengamati dan mendengarkan apa yang ditampilkan film strip dengan bantuan media Audio-Visual melalui Komputer dan LCD dengan seksama, dari hasil pengamatan peneliti murid sangat antusias memperhatikan dan menyimak apa yang ditampilkan media Audio-Visual melalui Komputer dan LCD, baik itu pada tindakan siklus 1 dan tindakan siklus 2.

Guru membimbing murid untuk membaca bacaan yang ditampilkan secara bersama-sama, sendiri-sendiri, serta berkelompok. Hal ini dilakukan untuk melihat seberapa besar antusias murid membaca bacaan secara perorangan dan berkelompok. Kegiatan murid pada tindakan siklus 1 telah sesuai dengan apa yang diarahkan guru, yakni murid membaca bacaan secara perorangan secara bergantian dan murid pun membaca bacaan secara berkelompok.

Kegiatan selanjutnya guru membimbing murid untuk mengemukakan isi bacaan yang dibacanya. Murid pun mengemukakan isi bacaan yang terkandung dalam bacaan, seperti murid menyebutkan tokoh dalam cerita dan menjelaskan apa yang dilakukan setiap tokoh dari bacaan tersebut, baik itu pada tindakan siklus 1 maupun tindakan siklus 2 dengan benar. Kegiatan ini dilakukan agar murid dapat memahami makna yang terkandung dalam isi bacaan, Selain itu juga guru menunjuk beberapa orang murid untuk menceritakan 
kembali isi bacaan yang telah dibacanya, muridpun menceritakan kembali isi bacaan tersebut dengan baik, namun pada pelaksanan tindakan siklus 1 , guru tidak membimbing murid untuk menceritakan kembali isi bacaan yang telah dibaca murid, nanti pada saat pelaksanaan pembelajarantindakan siklus 2. Kegiatan tersebut pada siklus 1 tidak dilakukan karena tidak tercantum pada tujuan pembelajaran untuk tindakan siklus 1 .

Kegiatan berikutnya adalah guru memberikan tes. Pelaksanaan tes dalam penelitian ini terdiri atas dua bagian yaitu, yaitu evaluasi proses dan evaluasi hasil. Evaluasi proses dilakukan selama berlangsungnya pembelajaran dengan menggunakan format pengamatan, baik aspek guu maupun aspek murid.

Kegiatan memberikan evaluasi hasil pada tahap ini berlangsung dengan baik. Evaluasi hasil pembelajaran pada setiap akhir siklus 1 dan 2 . evaluasi hasil dilaksanakan untuk menilai dampak pelaksanaan peningkatan minat belajar murid terhadap pencapaian pemahaman murid dari proses belajar yang dilakukan. Guru melakukan evaluasi dan pengamatan kepada murid dimaksudkan untuk mengetahui seberapa besar minat belajar dan pemahaman murid terhadap bacaan. Dari data hasil pengamatan guru, peneliti, dan teman sejawat pada tindakan siklus 1 dan tindakan siklus 2 ini terungkap bahwa murid sangat tertarik dan antusias mengikuti pelajaran membaca yang diajarkan guru dengan menggunakan film strip dengan bantuan media Audio-Visual melalui Komputer dan LCD, dimana minat belajar murid meningkat sedikit demi sedikit dari setiap siklus. Hal ini membuktikan bahwa penggunaan film strip dengan bantuan media Audio-Visual melalui Komputer dan LCD dalam meningkatkan minat belajar murid dalam pembelajaran membaca efektif dilakukan.

\section{Tahap Akhir/Tindak Lanjut}

Dari data hasil penelitian tindakan siklus 1 dan tindakan siklus 2, terungkap bahwa aktivitas guru dan murid pada tahap tindak lanjut pembelajaran membaca dengan menggunakan film strip dengan bantuan media Audio-Visual melalui Komputer dan LCD, guru melakukan kegiatan tindak lanjut setiap berakhirnya setiap siklus, hal ini dilakukan untuk. Kegiatan yang dilakukan guru adaiah melakukan refleksi untuk menemukan hambatan-hambatan selama proses pembelajaran membaca serta menemukan solusi. Hal ini dilakukan untuk mengetahui masalah yang dihadapi murid selama proses pembelajaran dengan menggunakan film strip dengan bantuan media Audio-Visual melalui Komputer dan LCD, yang kemudian dicarikan solusinya dan diperbaiki pada pertemuan tindakan siklus ke 2.

Pada siklus 1 aktivitas guru dan murid tidak mengalami hambatan, guru dan murid dapat menyelesaikan tugasnya dengan baik, hal ini tampak pada keberhasilan tujuan pembelajaran yang telah ditetapkan guru.

Kegiatan berikutnya guru membiimbing murid untuk menyimpukan isi materi pelajaran yang telah diajarkan. Hal ini untuk mengingatkan kembali kepada murid kakan inti materi pelajaran yang telah diajarkan. Pada siklus 1 kegiatan ini tidak berlangsung secara efektif, nanti pada kegiatan siklus 2 baru efektif, namun hal itu tidak mengganggu proses pencapaian indikator kriteria keberhasilan yang ditetapkan peneliti pada siklus 1, karena hasilnya telah sesuai dengan apa yang diharapkan oleh peneliti.

Setelah merefleksi, menyimpulkan guru juga memotivasi murid agar giat membaca buku baik dirumah dan disekolah, hal ini dilakukan untuk mengingatkan 
kepada murid untuk selalu mebaca dan mengulangi pelajarannya dirumah.

Peran media film strip dalam pembelajaran membaca sejalan dengan pendapat Arsyad (2002: 48) yang menyatakan bahwa filmstrip meningkatkan keterampilan siswa murid dalam membaca, karena media tersebut dapat melengkapi pengalaman-pengalaman dasar murid ketika membaca, berdiskusi, berpraktik, dan lainlain.

\section{Temuan Penelitian}

\section{Temuan Penelitian Tindakan Siklus 1}

Beberapa temuan yang diperoleh pada pelaksanaan tindakan 1 adalah sebagai berikut:

a. Murid merasa senang mengikuti pembelajaran membaca yang diberikan guru. Hal ini ditunjukkan dengan sikap aktif, dan antusias dalam pembelajaran membaca yang diberikan guru.

b. Penggunaan film strip dengan bantuan media Audio-Visual melalui Komputer dan LCD dalam pembelajaran membaca sangat menarik perhatian murid sehingga murid termotivasi untuk belajar.

c. Berdasarkan hasil wawancara dan angket dengan subjek penelitian untuk mengetahui tanggapan murid terhadap penggunaan film strip dengan bantuan media Audio-Visual melalui Komputer dan LCD dalam pembelajaran, murid beranggapan sangat senang mengikuti pelajaran yang diberikan guru.

d. Berdasarkan hasil tes yang diberikan, murid dapat memahami isi bacaan yang dibacanya dengan baik.

e. Murid yang mengalami kesulitan dalam membaca diberikan bimbingan oleh guru sehingga permasalahan yang dihadapi murid tersebut dapat teratasi. f. Kegiatan belajar membutuhkan waktu yang lebih lama dari waktu yang telah direncanakan. Alokasi waktu selama proses pembelajaran berlangsung 70 menit, tetapi pada waktu pelaksanaannya membutuhkan waktu 80 menit.

g. Berdasarkan pengamatan, wawancara, angket dan catatan lapangan maka tujuan pembelajaran yang diharapkan pada pembelajaran tindakan siklus 1 telah tercapai. Dengan demikian upaya menggunakan film strip dengan bantuan media Audio-Visual melalui Komputer dan LCD dalam meningkatkan minat belajar murid dalam pembelajaran membaca telah berhasil mencapai $66,33 \%$, hal ini belum sesuai dengan kriteria keberhasilan yang telah ditetapkan oleh peniliti yaitu tindakan setiap siklus dikatakan berhasil apabila sudah mencapai $80 \%$.

\section{Temuan Penelitian Tindakan Siklus 2}

Beberapa temuan yang diperoleh pada pelaksanaan tindakan siklus 2 , hampir sama dengan temuan pada tindakan siklus 1, yakni sebagai berikut:

a. Murid merasa senang mengikuti pembelajaran membaca yang diberikan guru. Hal ini ditunjukkan dengan sikap aktif, dan antusias dalam pembelajaran membaca yang diberikan guru.

b. Penggunaan film strip dengan bantuan media Audio-Visual melalui Komputer dan LCD dalam pembelajaran membaca sangat menarik perhatian murid sehingga murid termotivasi untuk belajar.

c. Murid terlibat aktif dan antusias dalam membaca baik secara individu, berpasangan maupun kelompok, dengan menggunakan/?/m strip dengan bantuan media Audio-Visual 
melalui Komputer dan LCD yang digunakan guru.

d. Penggunaan film strip dengan bantuan media Audio-Visual melalui Komputer dan LCD dalam pembelajaran membaca sangat membantu murid dalam memahami isi bacaan dengan baik, serta murid dapat lebih mudah menangkap isi bacaan dan menceritakan kembali isi bacaan tersebut dengan baik

e. Berdasarkan hasil wawancara dan angket dengan subjek penelitian untuk mengetahui tanggapan murid terhadap penggunaan film strip dengan bantuan media AudioVisual melalui Komputer dan LCD dalam pembelajaran, murid beranggapan sangat senang mengikuti pelajaran yang diberikan guru.

f. Berdasarkan hasil tes yang diberikan, murid dapat memahami isi bacaan yang dibacanya dengan benar.

g. Murid yang mengalami kesulitan dalam membaca diberikan bimbingan oleh guru sehingga permasalahan yang dihadapi murid tersebut dapat teratasi.

h. Berdasarkan pengamatan, wawancara, angket dan catatan lapangan maka tujuan pembelajaran yang diharapkan pada pembelajaran tindakan siklus 2 telah tercapai. Seperti halnya dengan tindakan siklus 1, tindakan siklus 2 dinyatakan berhasil, dengan demikian upaya menggunakan film strip dengan bantuan media AudioVisual melalui Komputer dan LCD dalam meningkatkan minat belajar murid dalam pembelajaran membaca telah berhasil, hal ini sesuai dengan kriteria keberhasilan yang telah ditetapkan oleh peneliti yaitu $80 \%$, tetapi pada tindakan siklus 2 ini keberhasilan murid mencapai $80,83 \%$.

\section{Simpulan}

Berdasarkan rumusan masalah, paparan data dan pembahasan hasil penelitian maka dapat disimpulkan sebagai berikut:

1. Perencanaan penerapan film strip dalam meningkatkan keterampilan membaca pemahaman teks cerita pada murid kelas IIISDN 174 Sukadamai Kecamatan Sukamaju Kabupaten Luwu Utara disusun secara terintegrasi dan kompleksitas sesuai dengan sistematika perencanaan pembelajaran. Namun, pada siklus I, perencanaan belum disusun secara lengkap dengan tidak tercantumnya metode yang dapat menunjang pelaksanaan media film strip. Hal ini telah diperbaiki pada siklus II sehingga keterampilan membaca murid mengalami peningkatan.

2. Pelaksanaan penerapan film strip dalam meningkatkan keterampilan membaca pemahaman teks cerita pada murid kelas IIISDN 174 Sukadamai Kecamatan Sukamaju Kabupaten Luwu Utara siklus I belum terlaksana dengan baik. Guru belum menerapkan media film strip sesuai dengan prosedurnya sehingga proses pembelajaran membaca belum maksimal. Pada siklus II, pelaksanaan film strip sudah sesuai dengan prosedurnya dan dapat diterapkan oleh guru dengan baik tanpa kendala yang signifikan. Hal ini berkontriubusi terhadap peningkatan keaktifan murid dalam membaca.

3. Hasil evaluasi menunjukkan bahwa hasil belajar murid dalam 
pembelajaran membaca dengan menggunakan film, strip dengan bantuan media Audio-Visual melalui Komputer dan LCD dari setiap siklus mengalami peningkatan yang sangat baik sebagaimana pada tindakan siklus 1 persentase keaktifan dan keantusiasan murid mengikuti pembelajaran mencapai $83,33 \%$, dan pada tindakan siklus 2 mencapai 95,83\%. Ketuntasan keterampilan membaca siklus I sebanyak 66,33\% dan meningkat pada siklus II menjadi $80,83 \%$.

\section{Daftar Pustaka}

Ambo Enre, Fachruddin. 1994. Dasardasar Keterampilan Menulis. Ujung Pandang: IKIP Ujung Pandang.

Aminuddin. 1990. Pengantar Apresiasi Karya Sastra. Bandung : Sinar Baru.

Arikunto, Suharsimi dkk. 2008. Prosedur Penelitian Tindakan Kelas. Jakarta: Rineka Cipta.

Arsyad, Azhar, 2002. Media Pengajaran.Jakarta: Raja Grafindo.

Depdikbud. 2005. Kamus Besar Bahasa Indonesia. Jakarta: Balai Pustaka.

Keraf, Gorys. 2005. Argumentasi dan Narasi. Jakarta: Gramedia.

Mustopo, Habib M. 1983. Ilmu Belajar Dasar, Kumpulan Esai Manusia dan Belajar. Surabaya: Indonesia Usaha Nasional.
Nurgiyantoro, Burhan. 2008. Penilaian dan Pengajaran Bahasa dan Sastra. Yogyakarta: BPFE.

Nurhadi. 2005. Membaca Cepat dan Efektif. Bandung: Sinar Baru Algesindo.

Oka, 1 Gusti Ngurah. 1983. Pengantar Membaca dan Pengajarannya. Surabaya: Usaha Nasional.

Rahiem, Farida. 2005. Pengajaran Membaca di Sekolah Dasar. Jakarta: Bumi Aksara.

Rahmanto, B. 1998.Metode Pengajaran Sastra. Yogyakarta: Kanisus.

Sagala, Syaiful. 2006. Konsep dan Makna Pembelajaran. Bandung: Alfabet.

Subana dan Sunarti. 2009. Strategi Belajar Mengajar Bahasa Indonesia, Bandung: Pustaka Setia.

Suharianto, S., 1982. Dasar-dasar Teori Sastra. Surakarta: WidyaDuta.

Suhendra, M. E. \& Supinah Pien. 1992. Pengajaran dan Keterampilan Membaca dan Keterampilan. Bandung : Pioner Jaya.

Supratiningsih. 2005. Pembelajaran Membaca, Jakarta: Depdiknas.

Tarigan, Henry Guntur. 1985. Membaca sebagai Suatu Keterampilan Berbahasa. Bandung : Aksara.

Tarigan, Henry Guntur. 1987. Teknik Pengajaran Keterampilan Berbahasa. Bandung: Rineka Cipta. 
Usman, Uzer Muh. 2004. Menjadi Guru Wiryodijoyo, S., 1989.Membaca: Strategi, Profesional.Bandung:PT

RemajaRosdakarya.

Pengantar, dan Tekniknya. Jakarta: Depdikbud. 